\title{
Survey work in Mesopotamia during the war
}

\author{
Lieut.-Col. G. A. Beazeley R.E.
}

To cite this article: Lieut.\#Col. G. A. Beazeley R.E. (1920) Survey work in Mesopotamia during the war, Scottish Geographical Magazine, 36:2, 94-106, DOI: $10.1080 / 00369222008734306$

To link to this article: http://dx.doi.org/10.1080/00369222008734306

册Published online: 27 Feb 2008.

Submit your article to this journal

Џ Article views: 5

Q View related articles ๘ 
to recent accounts, the country from Krasnovodsk on the Caspian to Samarkand is in the hands of the Bolshevists and their devastating propaganda. The movement unfortunately appears to be well organised, and, considering that 90 per cent. of the Russian population can neither read nor write, can scarcely be the work of an illiterate mob.

I would like to draw attention to the numerous German colonies scattered throughout the country not only in Russia proper but also in Central Asia. Now, whether these colonists be there as merchants or missionaries, they are Germans first and their other vocation ranks second. It is a curious coincidence that of two German colonies planted in Central Asia one is in the Khive district and the other on the route to Siberia, both on important lines of communication, and the former is situated in the midst of salt marshes, about the most unlikely spot to select for cultivation.

Khusk, of course, commands India, via Afghanistan, and Askabad Persia, via Meshid. We can only trust that the danger may be fully realised before it be too late, and that the necessary measures may be taken to avert what might be overwhelming disaster for the world.

\title{
SURVEY WORK IN MESOPOTAMIA DURING THE WAR.
}

\author{
By Lieut.-Col. G. A. Beazeley, R.E.
}

\section{(With Illustrations. ${ }^{1}$ )}

Conditions under which survey operations were carried out in Mesopotamia were very different from those existing on the Western front; the whole country was unsurveyed, the only maps available being the Indian degreo sheets, on the $\frac{1}{4}$-inch scale-a patchwork compiled from reports and travellers' sketches and skeleton irrigation surveys. Indeed, with the exception of small areas in Arabistan and along the Turko-Persian boundary, no survey worthy of the name existed.

Until triangulation based on Fau could be pushed up the more important rivers, Sir William Willcocks' irrigation maps were useful in providing a skeleton to tie down the preliminary air-photographic maps and advance survey reconnaissances, and for supplying approximate heights.

The work that fell to the surveyor in Mesopotamia, especially if he had the good luck to be on the Tigris front, was extremely interesting, and quite exciting and dangerous enough at times for the most ardent spirit. The parties got well known to the Turks, and occasionally had batteries told off to follow them about with their shells.

The area dealt with in this paper covers nearly the whole of Southern Mesopotamia up to the line Hit-Faluja-Samarra-Tuz Khurmatli. Gaps still occur in places where survey work was impossible at the time,

1 In reading this paper reference should be made to the map of the Baghdad Railway which appeared in the issue for March 1919.-ED. S. G.M. 
owing to the hostility of the Arabs and the inadvisability of detaching fighting troops to act as escorts; for such troops could not easily be spared from the fighting fronts or lines of communication. Portions of SW. Persia and the eastern fringe of the Arabian desert were also surveyed by the author's party.

Other areas in Mesopotamia and Persia have been surveyed in addition to those mentioned, but they do not come within the scope of this article, as the writer was captured by the Turks, and took no part in the work.

War surveys must primarily satisfy the military requirements of the field force, and after this advantage must be taken of any opportunities 6 to build up a reliable map of the country. Thus gaps still occur in the maps which are doubtless being filled up, now that the fighting is over.

The Survey of India (including some of its officers who had $\Xi$ temporarily reverted to military duty) undertook the whole of the survey work and mapping carried out in the areas mentioned above.

At the commencement of the campaign a survey party was formed under Colonel F. W. Pirrie, C.M.G., C.I.E., consisting of about 6 officers, $\ddot{Z} 20$ surveyors, and 200 men, to deal with all the field survey required. F The party was organised into three detachments as follows :--(1) Under $\checkmark$ Capt. W. E. Perry, M.C., R.E., with the Nasiriya column, with the Eown of that name as headquarters; (2) a small party under Lieut.Col. H. H. Turner, R.E., on the Tigris front, with its headquarters at Eli Gharbi ; and (3) the remainder of the party under Col. Pirrie, operating in the area behind those two fronts.

By September 1916 a considerable area of country on the $\frac{1}{2}$-inch scale had been surveyed, and triangulation pushed up as far as Kut, on the Tigris, and Nasiriya, on the Euphrates.

When General Sir Stanley Maude took over the command of the expeditionary force, the party was strengthened, and from October onwards the survey personnel was organised and carried on as follows:-(1) The Euphrates detachment as before, till the fall of Baghdad, when work was pushed rapidly forward up the Euphrates, and carried as far north as Hit and Faluja, and east as far as the Tigris. (2) Col. Turner was invalided to India and his place taken by Lieut.-Col. (then Major) G. A. Beazeley, D.S.O., R.E., in October 1916. His small party was attached to G.H.Q., and was responsible for survey work on the Tigris front till some time after the fall of Baghdad. In May 1917 his party was considerably strengthened, and its operations embraced all the country east of the Tigris, and as far north as the line Samarra-Tekrit-Tuz Khurmatli, and included a small portion of Persia east of Kizil Robat. (3) The remainder of the party, under Col. Pirrie, continued to operate on the unmapped area in the rear of these two detachments. After the fall of Baghdad Col. Pirrie was appointed Deputy Director of Field Surveys, in addition to his other duties, with headquarters at Baghdad. (4) In September 1916 Lieut.Col. P. C. Gunter, O.B.E., R.E., was placed in charge of map compilation under G.H.Q., and became responsible for all maps required by the field force, compiled from all available sources. 
A short description of the country which came under the sphere of survey operations will not be out of place. It may be divided roughly into five categories as follows :-(1) The swamps of lower Mesopotamia and the water-logged date groves along the lower reaches of the Tigris and Euphrates; (2) the perfectly flat arid wastes away from the river. banks, stretching from the swampy area in the south, right up almost as far north as Samarra. To the north of this limit we come to a gently undulating plateau gradually merging into the Jezireh, a rising plateau between the Tigris and Euphrates; (3) the narrow cultivated belt along the Tigris, Euphrates, and Dialah, with the canals fed from those rivers; (4) the barren cut-up foothills bordering on W. and SW. Persia; (5) the eastern fringe of the great Arabian desert to the west of the Euphrates, which is undulating, and rises gradually as one penetrates towards the west.

That ancient Mesopotamia was extraordinarily fertile and well populated is plainly evident from the remains and traces of numerous canals and cities met with everywhere. The wonderful system of canals that once made it the granary of the world should prove of great intierest to archæologists, and these will be dealt with later on.

Bitterly cold and damp as the country can be in the winter months, the heat in the summer is very great, the thermometer sometimes registering as much as $125^{\circ}$ in the shade. The winds are scorching, and combine with the terrible dust to make the climate very trying to the health under active service conditions. During the summer months at Samarra in 1917 work had to commence at 4.30 A.M., and by 10 A.M. instruments and metal work got too hot to hold, and no outdoor work could be resumed till within an hour of sunset.

The initial point of the survey operations was the Fau telegraph office, at the mouth of the Shatt-el-Arab, the geodetic co-ordinates of which had been previously accurately determined by the Survey of India. The longitudes of Baghdad and Kermanshah were obtained by wireless from Fau by means of pre-arranged signals and chronometers, the latitudes of these places having been previously determined: On these three places the whole of the triangulation was adjusted. The lines were carried up the more important rivers, and were also run at intervals into the deserts on either side whenever it was possible to secure armed escorts. These, however, could not always be spared.

No geodetic triangulation was attempted, nor first-class spiritlevelling; the destructive proclivities of the Arab, the unsettled state and the nature of the country, put all scientific survey out of the question. All that could be attained was tertiary triangulation, small theodolites, both vernier and micrometer, being used; short bases were measured with invar tapes at intervals, and the minimum number of angles observed consistent with reasonable accuracy in the results of the work. Triangulation was not only hampered by the flat nature of the country but by " mirage," especially in the hot weather, when distant objects disappeared at 10 A.M., and did not re-appear till 4.30 P.M.; this was accentuated by the extraordinary flatness of the ground. 
Dreary drab country it is too, mounds and mud-huts being only occasionally met with.

These conditions necessitated a very large number of short-sided triangles, making rapid progress impossible. Surveying parties had to be in by dark or remain out till dawn the next day, in consequence of sentries being given strict orders to fire at sight during the hours of night. This was necessary owing to prowling Arabs, who were arrant thieves. They frequently removed flags, poles, and pegs used for: marking stations, and thus added new difficulties to the work. They even sometimes removed the tins of the holes in the "putting" greens. of the golf links which were extemporised when a prolonged halt in one place admitted of the game being played.

Rain made the ground very slippery and muddy, and greatly retarded the walking powers of men on foot, and the progress of mechanical and wheeled transport. The writer of this article was once up to his shoulders in mud and water, in a hole into which his Ford van had run, heaving up the back wheel to enable his men to extricate the vehicle. It took two hours to do 17 yards that evening, two more holes having to be negotiated, and it was raining steadily at the time.

It can readily be imagined that under these circumstances it was impossible at times for triangulation to keep up with rapidly-moving columns, and other means of measuring horizontal distances had to be used until triangulation could again be resumed. The gaps left were subsequently filled up by the detachments working in rear, who completed the triangulation brought up from Fau.

Whenever distant prominent objects were visible to a flank they were often used as pivots, and enabled the advance triangulation to be pushed forward more rapidly. These points were generally minarets or domes of "Imams" (saints" tombs); occasionally an exceptionally tall, or isolated, palm tree, or a cairn on a high mound, was used.

North of Baghdad some of the junior officers of the provisional service in the Survey of India were very successful in cutting in prominent objects far ahead and utilising them to such advantage as to enable their triangulation to keep pace with moving columns. As much as fifteen or twenty miles a day were accomplished in this way, the results when worked out being accurate enough for all practical purposes. Two of these officers, Lieuts. Booth and Strong, were experts in this line. They put in exceptionally good work throughout the campaign, and were indefatigable.

In the swamp areas the surveyors worked from boats, the legs. of the plane tables being lashed to bamboos driven in to the bottom under the shallow water, where it did not exceed 10 feet in depth.

It was found impossible to locate the actual site of Willcocks' spiritlevelled bench marks, but the mean obtained from a group of three or four, obtained from one triangulation station, generally gave fairly. reliable values to work from, and prevented errors accumulating in the heights deduced from the triangulation. The slope of the country was vory slight; Baghdad, though 300 miles from the sea, is only about 108 feet above mean sea level. 
- Later on in the campaign Ford vans were used, and made it possible for the triangulation to proceed at a more rapid rate, as less time was required in selecting and marking stations and travelling to and fro observing.

When triangulation had to be dropped distances were measured with a cyclometer fitted to a bicycle wheel, direction being maintained by a 6-inch compass needle. In skilled hands a very accurate map can be prepared in this way, if deviation of the compass from true north is worked out every evening by astronomical observations. Towing a bicycle wheel behind a mechanical transport vehicle was tried, but soon put the cyclometer out of action. The best means of measuring distances with a wheel is to fit a revolution counter to the wheel of a "tonga" or covered cart to seat four persons, the circumference of the wheel being known. The larger diameter of the wheel gives more accurate results - than a bicycle wheel, and jars due to rough ground do not affect this form of measuring device. The surveyor and his two men also get a rest in the conveyance from point to point, and can cover much more ground and at a far more rapid rate than on foot pushing a bicycle wheel.

This form of transport has one great advantage over a motor vehicle, i.e. its ability to get over the sand and irrigation channels which so often bring the latter form to a standstill. The small party was subsequently nicknamed the "trick cyclists," and their approach sometimes gave rise to amusing comments.

The areas of survey based on (1) isolated bits of triangulation, (2) distances measured by wheel, were eventually fitted into the regular triangulation and adjusted; more complete surveys of the areas were also carried out.

The normal scale for areas outside the radius of military operations was $\frac{1}{2}$-inch to 1 mile. The 1 -inch scale was used where military requirements demanded it. Along the Tigris front, over ground where fighting was actually taking place or was likely to occur in the near future, the 3-inch scale was adopted, primarily to enable the batteries to fire by taking measurements straight off it. Even larger scales were demanded and issued in special cases. All maps on the 3 -inch and larger scales were compiled at first from air-photos tied down to fixed points, and subsequent editions were published after the maps had been revised and supplemented by ground survey. Later on the 3-inch maps were compiled from a combination of both or from ground survey only. The Air Force were told what areas to photo, and then handed copies to the map compilation department, who called on the Tigris front detachment to fix points within the photographed area, or used points fixed in advance.

These fixed points enabled the map compilation department not only to tie the photos down but to reduce each photo to the correct scale. Blue prints were then issued, the essential details being traced on boards and supplemented by ground survey. The contours were also put in, sometimes roughly by eye from the photos themselves in the shape of form lines. These maps proved most useful to the artillery for ranging purposes and in locating enemy targets. 
An officer or surveyor would sometimes be sent out into "No Man's Land" to fix points in enemy territory which could not be fixed from our own lines-an exciting job and not without risk of capture or surprise, for sometimes the returning parties had machine-guns turned on them from our own lines, and had some very lucky escapes.

The rapid way in which maps were reproduced and issued to the field force speaks very highly of the organisation under Col. Gunter. On reaching Baghdad a suitable building was allotted, and a machine press, driven by an electric motor, installed in addition to hand-presses. His drawing and reproducing staff was largely strengthened by craftsmen from home, but some of these had to be trained after joining.

Owing to the cut-up nature of the Jebel Hamrin Range and other similar hills, a good deal of hard work was thrown on the surveyors contouring the ground; but over the great Mesopotamian plain no contouring was necessary except along the southern fringe of the Jezireh, in the neighbourhood of Samarra.

Great credit is due to the Royal Air Force for their untiring efforts in air-photography, and to Col. Gunter who dealt with these photographs; ground in enemy territory denied to our own surveyors was rapidly mapped in this fashion, on a framework of fixed points. As soon as the military conditions permitted, the maps were revised and supplemented by ground survey and issued to the field force in complete form.

In addition to their normal survey duties, the small Tigris detachment was also responsible for $(a)$ providing batteries with artillery boards, $(b)$ assisting in fixing battery positions, $(c)$ supplying the co-ordinates of points and targets in enemy territory, etc. The work was of a very arduous nature along the Tigris front from Shumran towards Sannaiyat, and kept the small party very busily employed all day, and frequently well into the night.

To the party was also assigned the duty of erecting landmarks to guide the troops along the maze of roads behind the fighting line. These roads at night looked all alike, for no natural features enabled one to pick out the right route. The troops were thus liable to get lost, so that these landmarks, when picked up by night, were most useful. The marks consisted of poles up to 25 feet in height, stayed by wire, and surmounted by gunny bags stuffed with grass and scrub, and arranged in different patterns to distinguish one from another. Below these were sign-posts, and the combination enabled one to find one's way to one's destination, but the posts were frequently stolen for firewood.

Another job which fell to the survey party was the running of spiritlevelled heights along the firing line, in order to determine the height an embankment should be built to keep the water from flooding the trenches, the country, and the lines of communication in rear, should the Turks cut the Tigris embankments in flood-time. As an ordinary levelling stave could not be used, two 2-foot and 5-foot staves were made and a theodolite used as a level, on its box or a flat board. The work was carried along closely in rear of the trenches, work in the trenches themselves being impossible. The observer and his men had to crawl along in the mud on their stomachs, to avoid being targets to 
snipers, who were always on the look-out for anybody who put his head above the parapet. One stave was pierced by a bullet, and the top of the observer's head was once so closely shaved by another bullet as to give him a headache. The weather was wet and damp, and added to the discomfort of the work.

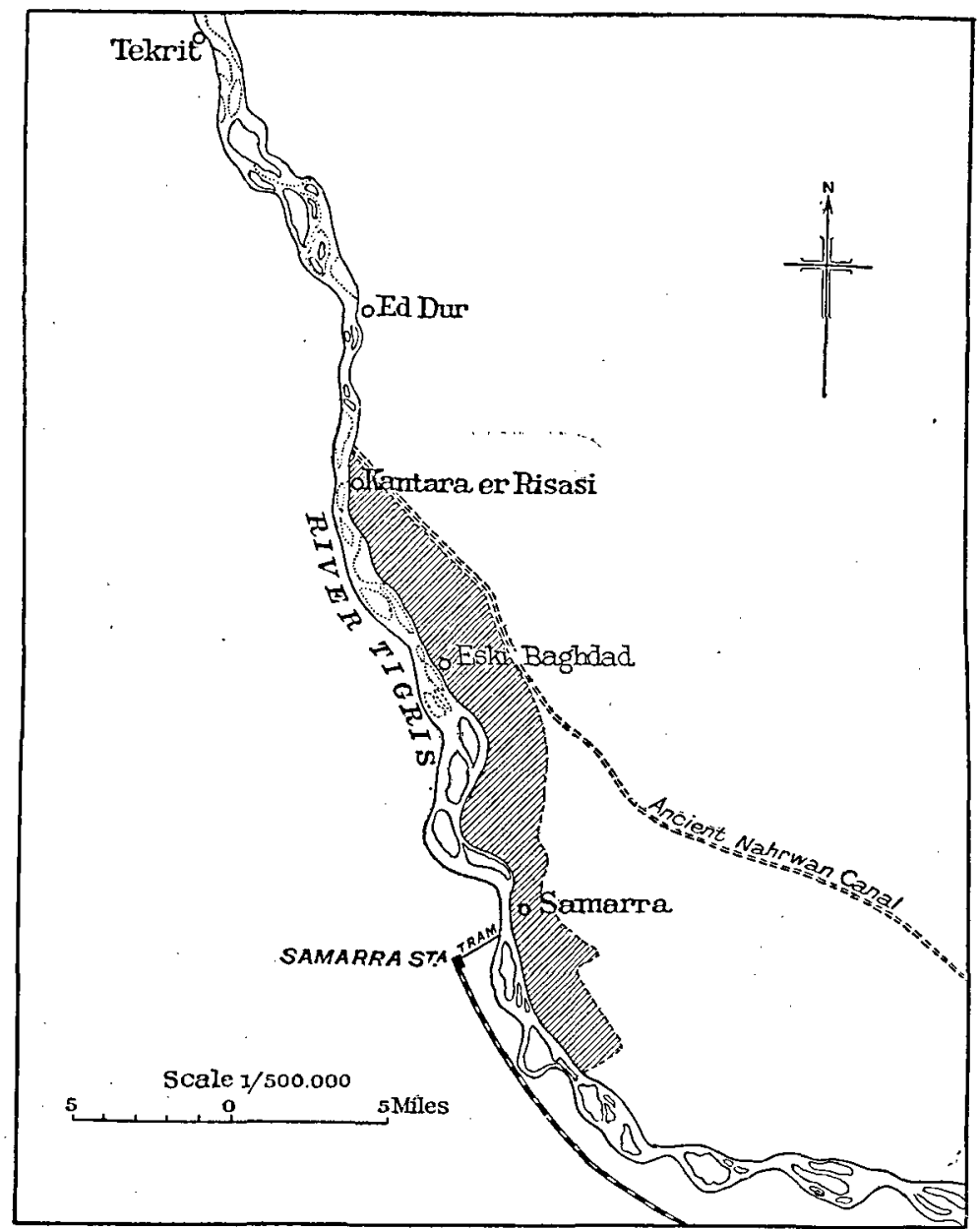

Sketch-map to show: ruins on the Tigris around Samarra, as seen from the air.

The theodolite of the party became very well known to the Turks, who sometimes shelled it, and when we were observing close to or behind the firing line, the instrument was placed near some bank or ditch whenever possible, so as to enable the observer to take cover whenever a shell was heard approaching, a most disconcerting experience when one was reading angles. The want of a periscopic theodolite such as was used on the Western front was badly felt. 


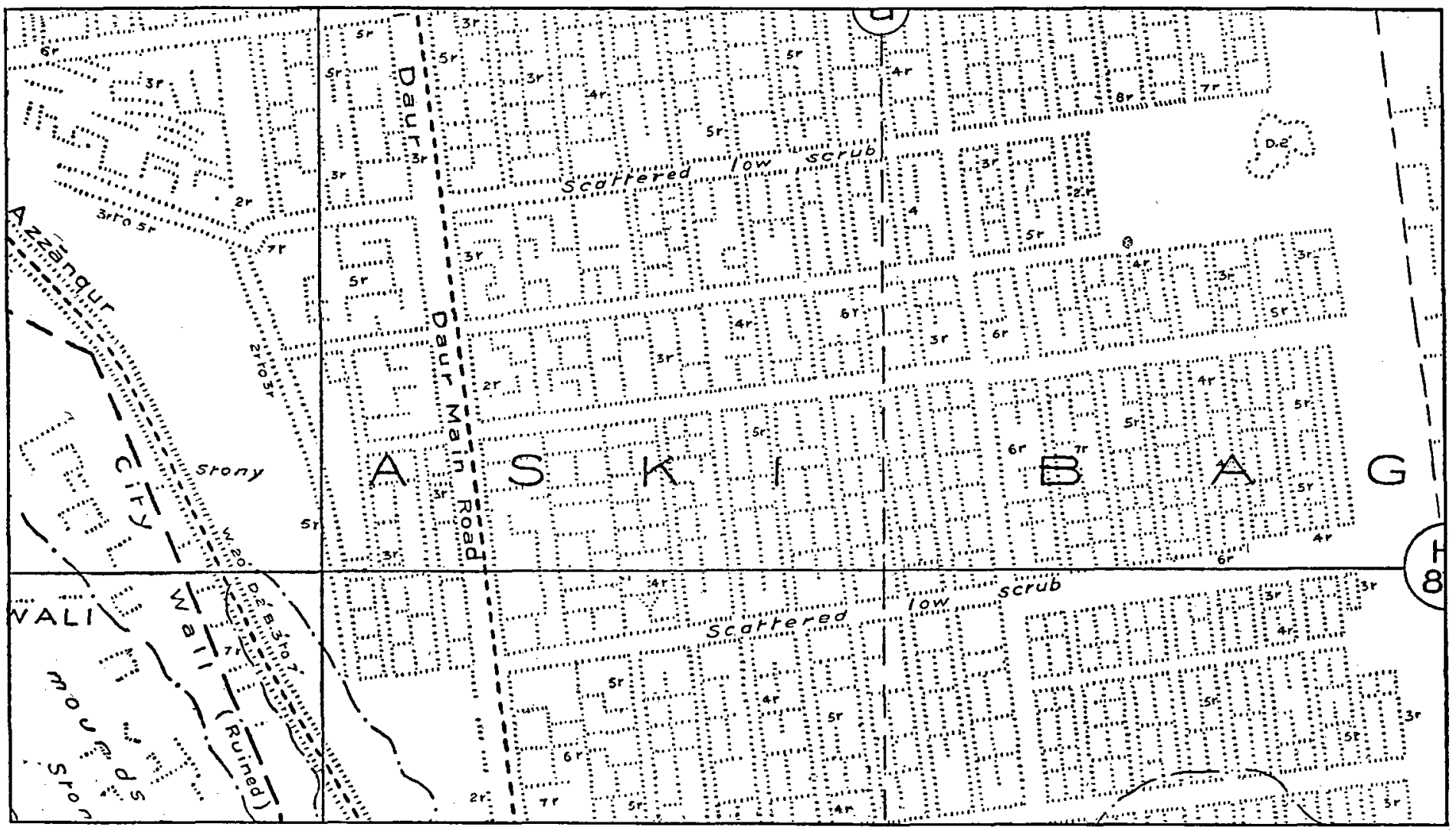

Fra. 1.--Part of the Northern Quarter of the ruined city of Eski Baghdad. 
The work of providing artillery boards and "spotting" was chiefly done for the counter-batteries. The artillery boards furnished were of two kinds :-(1) "Skeleton" boards with the observing ladders, position of centre of battery, objects in enemy territory, and reference marks accurately plotted on a "grid" to correspond with that drawn in on the 3 -inch map covering the same ground. Other points and detail were added as required. The mutual bearing to the nearest minute between the ladders and the centre of the battery were given. The gunners did the rest. (2) In addition to the above the 3-inch map was cut up into small squares and adjusted on the board, so as to disperse any error in scale or bearing. Drawing paper mounted on white cardboard was used for the boards, as thin zinc plates were not available. Boards were renewed when required, a duty which involved a good deal of night work to ensure the boards being issued before dawn the next day.

The positions of enemy batteries were sometimes fixed as follows :a theodolite was set up by an assistant at the foot of an observing ladder, or in an elevated O.P., while the observer ascended and observed the flash. If at the top of a ladder he descended, observing, as he did so, what detail he could see from the ground coincided with the direction of the flash, and then took a set of observations to it. The party then motored or walked over to the second O.P. or ladder, and repeated the operation for two or more flashes, a return to the first point being made for verification of observations. The results were rapidly worked out on the spot. It is only fair to say that the system sometimes failed, as the flash did not always proceed from the same gun. It was impossible for the small party to do more, owing to lack of personnel, and it was not equipped with sound-ranging and flash-spotting instruments. But its members had the satisfaction of knowing that its efforts were sometimes successful, and contributed to the heavier enemy batteries being neutralised.

The original small Tigris front party followed the fortunes of the troops and entered Baghdad the day it was captured. It accompanied the columns operating beyond at Shahroban and on the Marl Plain near Deli Abbas. It then transferred its activities elsewhere, and was present at the battle of the Adhaim crossing; it was also present at the battle of Istabulat which resulted in the fall of Samarra, and marched with the column it was attached to up the Adhaim River and saw all the fighting there.

In the summer months of 1917 , it formed the nucleus of the party sent to Samarra to work there, and was present at all the fighting that took place beyond Shahroban in the Jebel Hamrin in the winter that followed and in the spring of 1918 .

To the credit of the Nasiriya detachments falls the work done during the fighting on the Euphrates, terminating in the successful "coups" at Ramadiyeh and Hit in December 1917 and March 1918 respectively. Captain Perry was subsequently sent to Kermanshah, attached to the Russians there, and carried out a good deal of $\frac{1}{2}$-inch survey in that area. He had many obstacles put in his path, but successfully surmounted them.

On the fall of Baghdad, an accurate large-scale map of the city was 


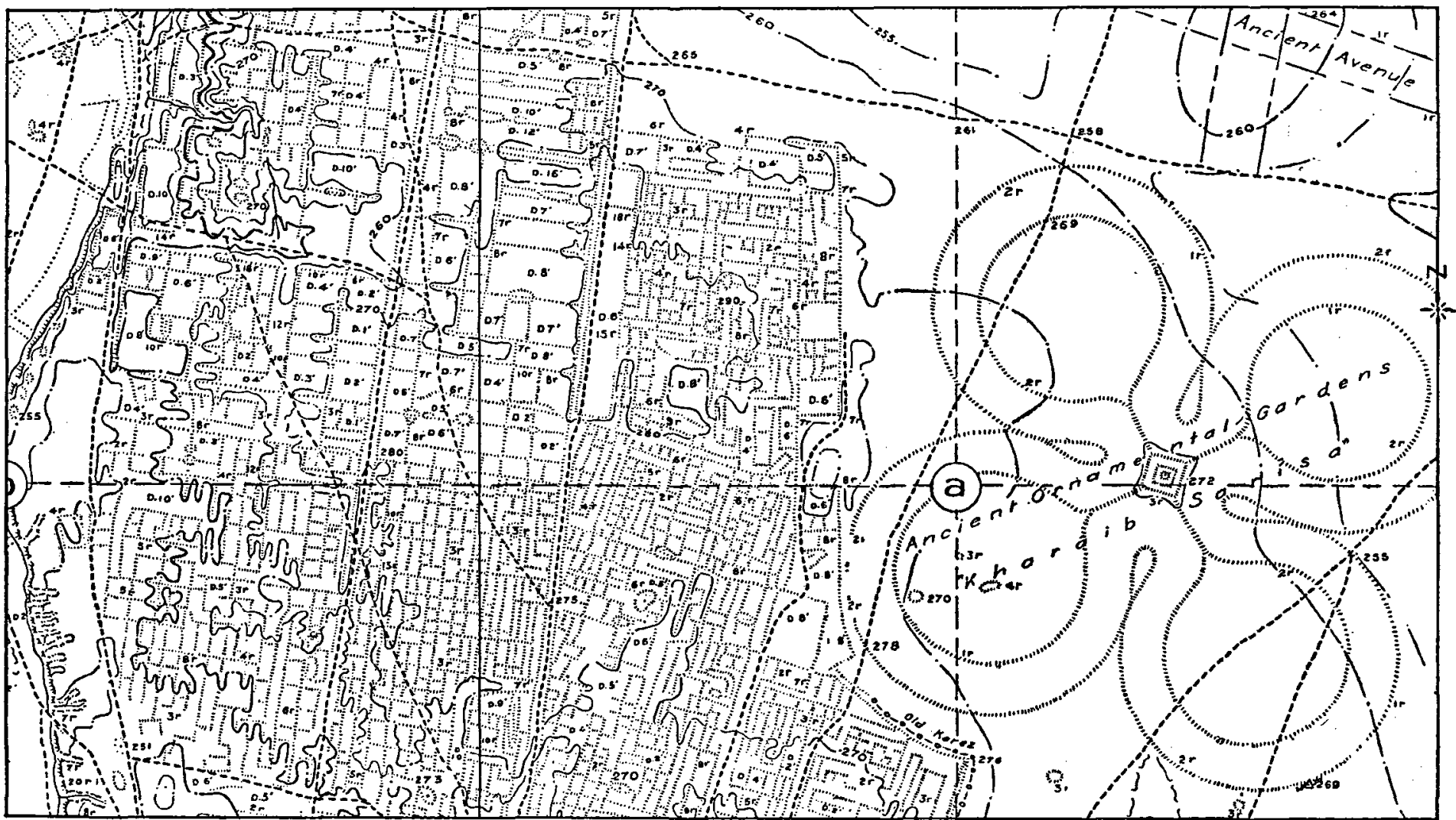

FIG. 2.-Central part of city with Public Gardens. 
badly needed, and the Tigris detachment was detailed for this. But as its services were urgently required elsewhere it was decided to try an air-photographic survey, and this was taken up by the map compilation

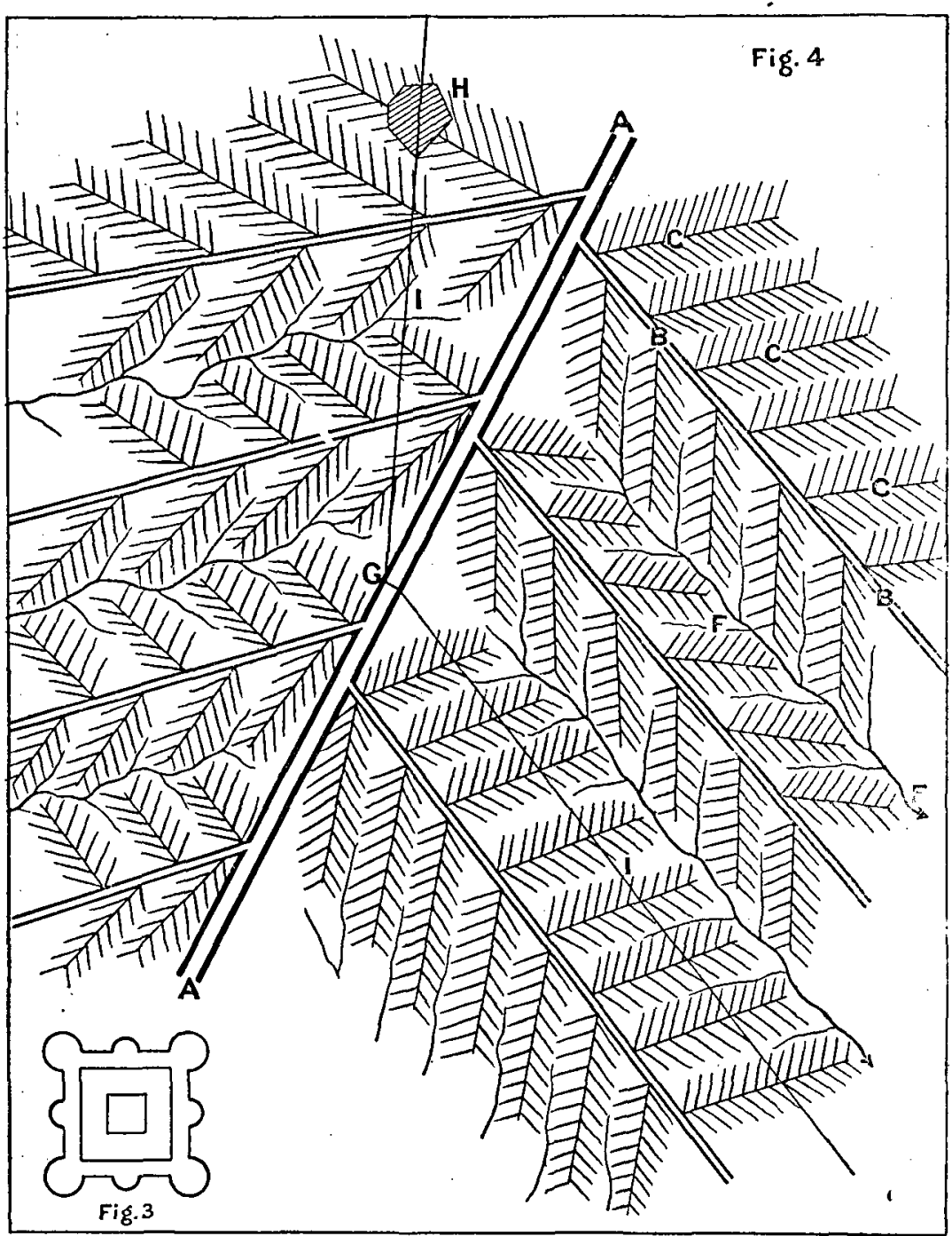

FIG. 3.-PIan of detached Forts of ancient City.

Fia. 4.-Plan of ancient Irrigation System.

department. A number of points had already been fixed by triangulation by the Tigris party, and more were fixed by plane table intersection, and a map produced from the photos on the 12-inch scale proved quite successful. The map was completed in about a fortnight 
by the map compilation department. To have carried the same operation out by ground survey would have taken several weeks, and have absorbed quite a number of surveyors badly needed elsewhere.

When a larige-scale survey of the neighbourhood of. Samarra was called for by the military authorities, it was decided to call in the aid of air-photography, and complete the rest of the detail and contouring by supplementary survey. The scale chosen was the 6 -inch, and the total area surveyed was 120 square miles.

The air photographs were adjusted to fixed points, the congregated sheet being reduced to the 6 -inch scale, and blue prints made and issued to the surveyors, who traced whatever detail was required on the boards and carried out the contouring and supplementary detail survey on the ground. The photos, however, plainly revealed the profile of a very large ancient city. Traces of walls, foundations, rooms, public gardens, etc., which were not visible to any one walking over the ground, showed up quite plainly in the photographs, and revealed the fact that surveys of areas for archæological research can in future be greatly assisted by air-photography.

The illustrations given ${ }^{1}$ afford a good idea of portions of this city. The most remarkable feature is the fine public ornamental garden, in the centre of which must have stood once a very fine pavilion (Fig. 2). The northern portion of the city is in plan very like a modern American city (Fig. 1). The epoch at which the city was built is still in doubt, but it appears to have been built before the birth of Christ, and may possibly have been passed by Xenophon in his retreat.

Figs. 3 and 4 are objects seen while the writer was in the air, the former being a sample of remains of ancient forts, the latter an ancient scientific irrigation system with a village site and a through.route. Remains of bricks were found afterwards at $G$, showing that a bridge had once spanned the main canal. The writer was able to go over the ground in an armoured car, and the sketch was drawn from memory and shows how the water was distributed to the fields. All surplus water appears to have been returned along the depressions to the canals again, so that none was wasted.

Fig. 5 is a large-scale survey of one of the large ancient canal regulator systems east of Samarra.

The wonderful system of canals that once made Mesopotamia the granary of the world should prove of great interest to archæologists. For miles traces of these grand works stretch into the desert, with their branches radiating in all directions. Remains, of ancient cities and connecting roads also abound everywhere.

The writer had hoped ere he left Mesopotamia to get permission to survey all these grand evidences of a past civilisation, both from the air and on the ground; but, while carrying out an air reconnaissance over the enemy lines, his machine was shot down and he was captured by the Turks, and thus lost all chance of doing so. It will fall to others to unravel the wonderful system of irrigation and other evidences of this country's grand past.

${ }^{1}$ By kind permission of the Royal Geographical Society, who have also lent the blocks.

voL. XXXVI. 
A rapid means of topographical survey from an aeroplane was evolved by the writer to take the place of air-photography when time or circumstances did not permit of the latter process. Special fittings were designed and used for the purpose. As this required the services of a trained surveyor, and nobody else was available at the time, he took up the work in addition to his other duties. The system was used when a map was required of unmapped country, over which

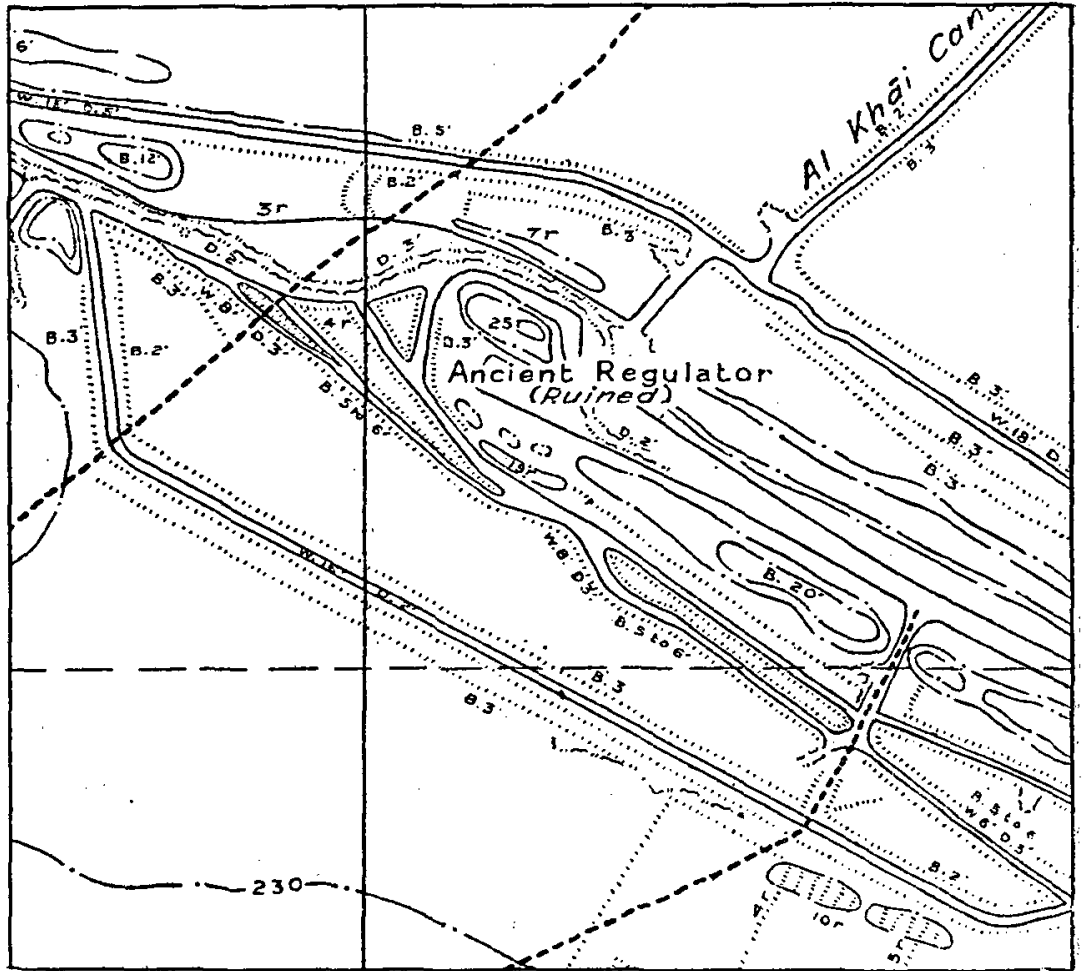

Fig. 5.-Air survey of ancient canal regulator system.

operations would shortly take place. The work was taken to the map compilation department, and the map compiled there and issued to the troops before they reached the ground. As much as 400 square miles could be done in two hours provided there was not too much detail to put in. Five very interesting and exciting trips were made by the writer over enemy territory, the aeroplane he was in being shot down on the sixth venture.

By this method inaccessible and unsurveyed areas in arid countries, where it is not advisable to go to the expense of air-photography, can be surveyed. Further experiments have just been carried out in England by the writer. 